\title{
EFFECT OF P-DELTA IN SEISMIC ANALYSIS OF MULTISTOREY BUILDINGS
}

\author{
ManikRao $^{1}$, Rajendrakumar S Harsoor ${ }^{2}$ \\ ${ }^{1} M$. Tech Scholar, Department of Civil Engineering, PDA College of Engineering, Kalaburagi, VTU, Karnataka, India \\ ${ }^{2}$ Dean \& Professor, Department of Civil Engineering, PDA College of Engineering, Kalaburagi, VTU, Karnataka, \\ India
}

\begin{abstract}
The behavior of structures, when subjected to critical loads is a complex phenomenon and is basically dependent on the type of forces/loads acting on the structure, magnitude of force, direction etc. In this paper the effect of P-Delta on multi storey buildings is studied. The four models i.e. 5, 10, 15, and 20 storey are modelled and analyzed using ETABS v 13.1 software. The non-linear static analysis is performed to account for the P-Delta effect on the four types of building models and is compared with linear static analysis using ETABS v. 13.1. The variation in the axial forces, storey shears, displacements and bending moments with and without the consideration of P-delta effect is compared. The results have shown that, the models analyzed with considering $P$ delta effect (non-linear static analysis) have significantly more values of displacements, axial forces, bending moments and storey shears when compared with the models without considering the P-delta effect (linear static analysis). Therefore, the P-Delta effect is significant and must be considered in the analysis of multi storey buildings.
\end{abstract}

Keywords- Linear static analysis, P-delta effect, nonlinear static analysis, ETABS v. 13.1.

$* * *$

\section{INTRODUCTION}

From a structural engineer's point of view tall building or multistoried building is one that, by virtue of its height, is affected by lateral forces to an extent that they play asignificant role in the analysis and design of structures. Due to complexity and lack of knowledge of P-Delta analysis, designers, engineers and architects perform Linear Static analysis, which may eventually become a cause of catastrophic collapse of the multistoried building.

Generally Structural designers are prone to use the linear static analysis, which is also known as first order analysis, to compute design forces, moments and displacements resulting from loads acting on a structure. First order analysis is performed by assuming small deflection where the resulting forces, moments and displacements take no account of the additional effect due to the deformation of the structure under vertical load prior to imposing lateral loads.

The term P-delta refers to the additional actions induced by an axial force $(\mathrm{P})$ when there is a horizontal displacement (delta) on a vertical element. P-Delta is a non-linear (second order) effect that occurs in every structure where elements are subject to axial loads. It is a genuine "effect" that is associated with the magnitude of the applied axial load (P) and a displacement (delta). If a P-Delta affected member is subjected to lateral load, then it will be prone to deflect more which could be computed by P-Delta analysis and not by the linear static analysis. This effect may reduce significantly the flexural capacity of a structure.
The magnitude of P-delta effect is related to the:

* Magnitude of axial load.

* Stiffness/slenderness of the structure as whole.

* Slenderness of individual elements.

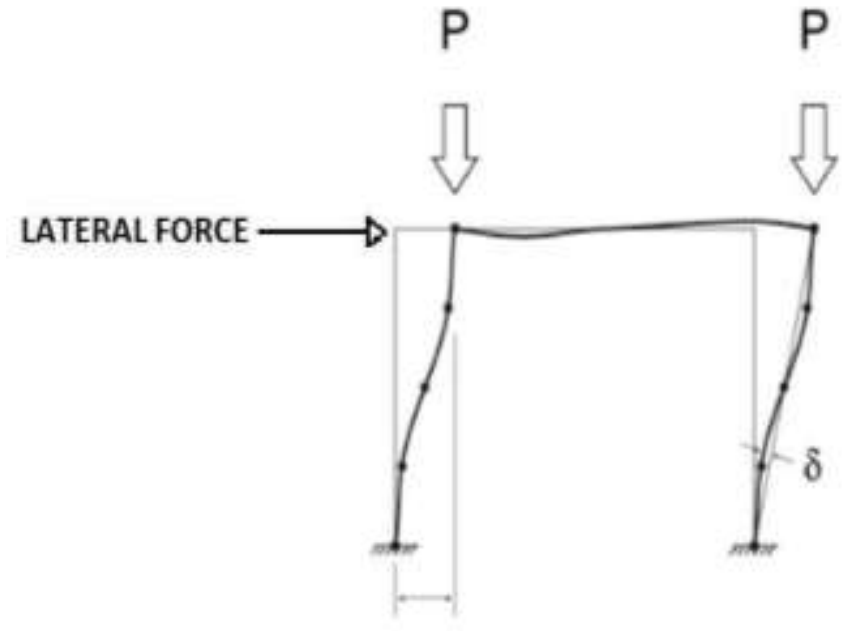

$\Delta$

Fig 1 Schematic representation of P-delta effect on a frame

\section{LITERATURE REVIEW}

Christoph ADAM ${ }^{\mathbf{1}}$, Luis F. IBARRA ${ }^{\mathbf{1}}$ (2004), addresses the assessment of destabilizing effects of gravity, usually referred to as P-Delta effects, in highly inelastic structures when subjected to seismic excitations. The proposed approach is based on an equivalent single-degree-offreedom (ESDOF) system of the actual building. 
Appropriate properties of the ESDOF system are defined, based on results of a corresponding global pushover analyses. P-Delta effects are incorporated via an auxiliary backbone curve, which is rotated by a uniform stability coefficient. The procedure is evaluated for several multistorey generic frame structures. The collapse capacity of these structures is derived from a set of Incremental Dynamic Analysis (IDA) studies involving 40 ground motions whose intensity is increased until P-Delta instability occurs. The results are translated from the ESDOF domain into the domain of the multi-degree-of-freedom (MDOF) system, and utilized for the estimation of P-Delta effects in MDOF structures. "Exact" results are contrasted with outcomes of the analyses utilizing ESDOF systems. Assumptions and limitations of the ESDOF system approach are discussed. The emphasis is on the level of response at which the structure approaches dynamic instability (sidesway collapse).

A.S. Moghadam ${ }^{2}$, A Aziminezad (2004) ${ }^{2}$, evaluated the importance of asymmetry of building on the P-Delta effects in elastic and inelastic ranges of behavior. The contribution of lateral load resisting system, number of stories, degree of asymmetry, and sensitivity to ground motion characteristics are assessed. Four buildings with 7, 14, 20 and 30 storey are designed based on typical design procedures, and then their elastic and inelastic static and dynamic behavior, with and without considering P-Delta effects, are investigated. Each building is considered for $0 \%, 10 \%, 20 \%$ and $30 \%$ eccentricity levels. The results indicate that the type of lateral load resisting system plays an important role in degree that torsion modifies the P-Delta effects. It is also shown that although in the elastic static analyses, torsion always magnifies the P-Delta effects, but the same is not always true for dynamic analyses. The results of dynamic analyses also show high level of sensitivity to ground motion characteristics.

T.J. Sullivan 6 , T.H. Pham ${ }^{6}$ (2008), the design of a 45storey reinforced concrete frame-wall case study structure is used to highlight the significance of the p-delta limit within the modal response spectrum analysis procedure of the Euro code 8. It is found that the strength of the structure is dictated by the P-delta limit for seismic actions, despite anticipated storey drifts and ductility demands being relatively low. A series of non-linear time-history analyses using a suite of spectrum-compatible real and artificial accelerograms, indicate that P-delta effects do not have a significant influence on displacements or storey drifts of the tall building. The likely causes of this behavior are identified, making reference to earlier investigations into Pdelta behavior and with consideration of substitute structure concepts. To investigate the significance of the P-delta ratio further, a series of SDOF studies are undertaken for systems designed with P-delta ratios of up to 0.85 . The results demonstrate that the p-delta ratio has little influence on the behavior of long-period systems subject to real earthquake records and therefore it does not appear appropriate to impose strict limits on the P-delta ratio. Instead, it is recommended that the P-delta effects be evaluated for tallbuilding systems as part of an overall assessment of their response, using advanced non-linear time-history analyses with real records and within a large-displacement analysis regime.

Jose Antonio Flores Ruiz $^{8}$ (2015), studied the effect of Pdelta on four, six and twelve storey RC frame building. A series of non-linear time history analyses using Takeda hysteric rule considering the P-delta effect was studied. It was shown that P-delta effects have a significant influence to the response even for the four and six storey structures and concluded that P-delta effect should always be included in the design and analysis of structures.

\section{METHODOLOGY}

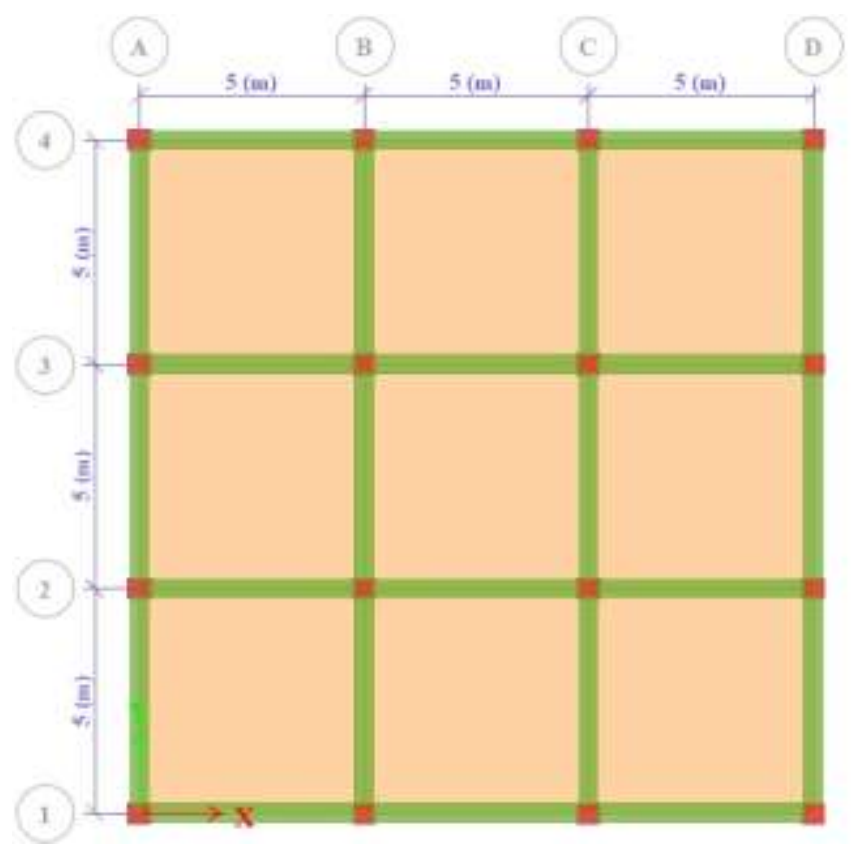

Fig 2 Typical Plan of the models

As mentioned earlier, to observe the effects of P-delta, four different storey cases are taken where storey variation starts from storey 5 to storey 20. Each of the storey case is performed linear Static and P-delta analysis separately with appropriate command. Each storey is 3 metre in height makes Storey 5, storey 10, storey 15 and storey 20 in total height of $15 \mathrm{~m}, 30 \mathrm{~m}, 45 \mathrm{~m}$, and $60 \mathrm{~m}$. As storey increase so the slenderness increases. Bay length of the buildings in both directions is $5 \mathrm{~m}$. 
Table 1:- Dimensions, Grade of concrete and grade of steel for different models

\begin{tabular}{|c|c|c|c|c|c|c|}
\hline Model & $\begin{array}{l}\text { Beam size } \\
(\mathbf{m m X m m})\end{array}$ & $\begin{array}{l}\text { Column } \\
\text { size } \\
(\mathbf{m m X m m})\end{array}$ & $\begin{array}{l}\begin{array}{l}\text { Slab } \\
\text { thickness } \\
(\mathbf{m m})\end{array}\end{array}$ & $\begin{array}{l}\text { Wall } \\
\text { Thickness } \\
(\mathbf{m m})\end{array}$ & $\begin{array}{l}\text { Grade of } \\
\text { concrete } \\
\left(\mathrm{N} / \mathbf{m m}^{2}\right)\end{array}$ & $\begin{array}{l}\text { Grade of } \\
\text { steel } \\
\left(\mathrm{Nmm}^{2}\right)\end{array}$ \\
\hline $\mathrm{G}+4$ & $400 \times 450$ & $450 \times 550$ & 150 & 300 & M25 & FE500 \\
\hline $\mathrm{G}+9$ & $450 \times 500$ & $500 \times 550$ & 150 & 300 & M25 & FE500 \\
\hline $\mathrm{G}+14$ & $400 \times 450$ & $450 \times 500$ & 150 & 300 & M25 & FE500 \\
\hline $\mathrm{G}+19$ & $500 \times 600$ & $550 \times 650$ & 150 & 300 & M25 & FE500 \\
\hline
\end{tabular}

Load Calculations: Following loads are considered for the analysis of the buildings. The loads are taken in accordance with IS: 875 (Part 1) and (Part 2).

\subsubsection{Dead Load}

\subsubsection{Live Load}

a) Intensity of live load on intermediate floors $=3 \mathrm{kN} / \mathrm{m}^{2}$

b) Intensity of live roof load on roof $=1.5 \mathrm{kN} / \mathrm{m}^{2}$

\subsubsection{Lateral Loads for P-Delta Analysis}

As per IS 1893:2002 for zone 5,

Zone factor $=0.36$

Soil: Type 2

Importance factor $=1$

\subsection{Load Combinations}

As per IS 1893 (Part 1): 2002, the load combinations are considered.

1) $1.5(\mathrm{DL}+\mathrm{IL})$

2) $1.2(\mathrm{DL}+\mathrm{IL}+\mathrm{ELX})$

3) $1.2(\mathrm{DL}+\mathrm{IL}$ - ELX)

4) $1.2(\mathrm{DL}+\mathrm{IL}+\mathrm{ELY})$

5) $1.2(\mathrm{DL}+\mathrm{IL}-\mathrm{ELY})$

6) $1.5(\mathrm{DL}+\mathrm{ELX})$

7) 1.5 (DL - ELX)

8) $1.5(\mathrm{DL}+\mathrm{ELY})$

9) 1.5 (DL - ELY)

10) $0.9 \mathrm{DL}+1.5 \mathrm{ELX}$

11) $0.9 \mathrm{DL}-1.5 \mathrm{ELX}$

12) $0.9 \mathrm{DL}+1.5 \mathrm{ELY}$

13) $0.9 \mathrm{DL}-1.5 \mathrm{ELY}$

\subsection{Analysis Methods}

\subsubsection{Linear Static Analysis or Equivalent Static} Analysis

The linear static analysis for $(\mathrm{G}+4),(\mathrm{G}+9),(\mathrm{G}+14)$ and $(\mathrm{G}+19)$ storey building is carried out without considering the P-delta effect in ETABS v13.1 program. From the analysis results, displacements, storey shear, axial force and bending moment at the base and at various structural members are obtained.

\subsubsection{Non-Linear Static or P-Delta Analysis:}

The nonlinear static analysis for $(\mathrm{G}+4),(\mathrm{G}+9),(\mathrm{G}+14)$ and $(\mathrm{G}+19)$ storey building is carried out considering the P-delta effect in ETABS v13.1 program. From the analysis results, displacements, storey shear, axial force and bending moment at the base and at various structural members are obtained.

\section{RESULTS AND DISCUSSIONS}

\subsection{Case 1 - 5 Storey Model}

The undeformed shape and deformed shape of the 5 storey model is as shown in fig. 3 and 4 respectively. The values of displacements, storey shear, axial force and bending moments for 5 storey model that are obtained by linear analysis and P-Delta analysis are tabulated in table 2. The values of displacements, storey shear, axial force and bending moments from linear analysis and P-Delta analysis are compared and variations as percent between the two types of analysis are evaluated and tabulated.

The variation of displacements, storey shear, axial force and bending moment obtained from linear static analysis and Pdelta analysis are plotted in graphs as shown in fig.5, 6, 7 and 8 respectively. 


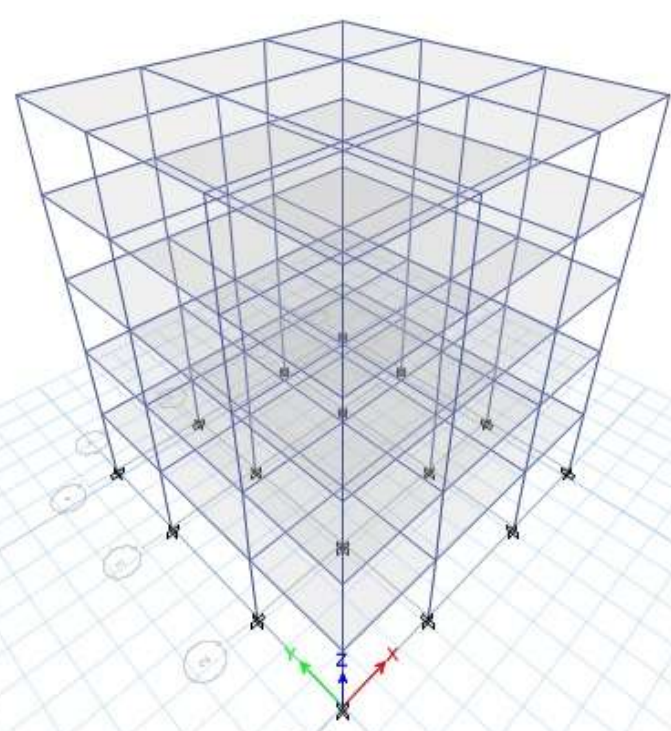

Fig 3. Undeformed shape of 5 storey model

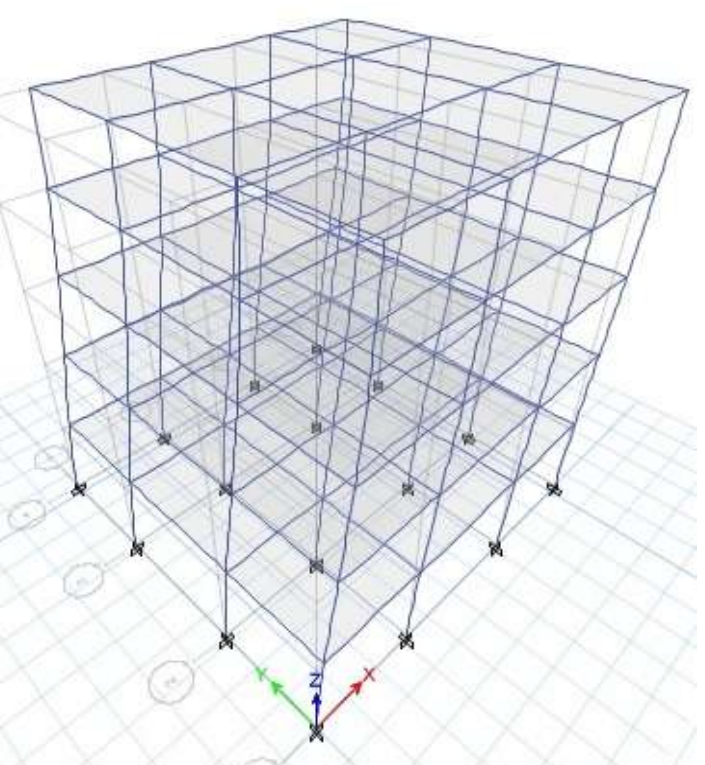

Fig 4. Deformed shape of 5 storey model

Table 2 Values of displacements, Storey shear and bending moment for 5 storey model

\begin{tabular}{|l|l|l|l|l|l|l|}
\hline \multirow{2}{*}{$\begin{array}{l}\text { NO OF } \\
\text { STOREYS }\end{array}$} & \multicolumn{2}{|l|}{ DISPLACEMENT $(\mathrm{mm})$} & \multicolumn{2}{l|}{ STOREY SHEAR(kN) } & \multicolumn{2}{l|}{ MOMENT(kN-m) } \\
\cline { 2 - 7 } & $\begin{array}{l}\text { LINEAR } \\
\text { STATIC } \\
\text { ANALYSIS }\end{array}$ & $\begin{array}{l}\text { P-DELTA } \\
\text { ANALYSIS }\end{array}$ & $\begin{array}{l}\text { LINEAR } \\
\text { STATIC } \\
\text { ANALYSIS }\end{array}$ & $\begin{array}{l}\text { P-DELTA } \\
\text { ANALYSIS }\end{array}$ & $\begin{array}{l}\text { LINEAR } \\
\text { STATIC } \\
\text { ANALYSIS }\end{array}$ & $\begin{array}{l}\text { P-DELTA } \\
\text { ANALYSIS }\end{array}$ \\
\hline 5 & 15 & 21.5 & 315.0487 & 393.8085 & 54787 & 57259 \\
\hline 4 & 13.2 & 19.2 & 533.9948 & 667.4853 & 109575 & 116990 \\
\hline 3 & 10.3 & 15.2 & 657.152 & 821.4246 & 164362 & 176720 \\
\hline 2 & 6.7 & 9.8 & 711.8885 & 889.8413 & 219937 & 236451 \\
\hline 1 & 2.9 & 3.9 & 725.5727 & 906.9532 & 273937 & 296182 \\
\hline 0 & 0 & 0 & 725.5727 & 906.9532 & 273937 & 296182 \\
\hline
\end{tabular}
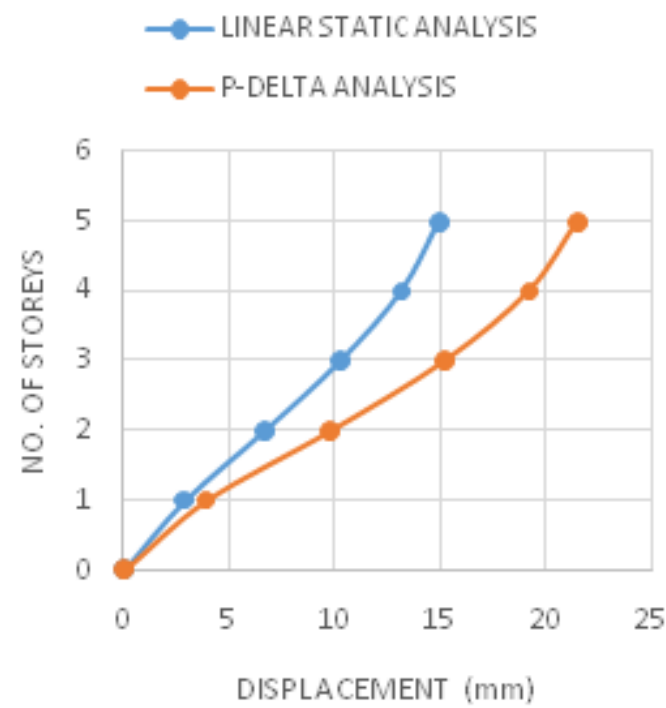

Fig. 5: Variation of displacement for the no. of storeys Fig.6: Variation of Storey shear for the no. of storeys obtained from linear and P-delta analysis for 5 storey model obtained from linear and P-delta analysis for 5 storey model 


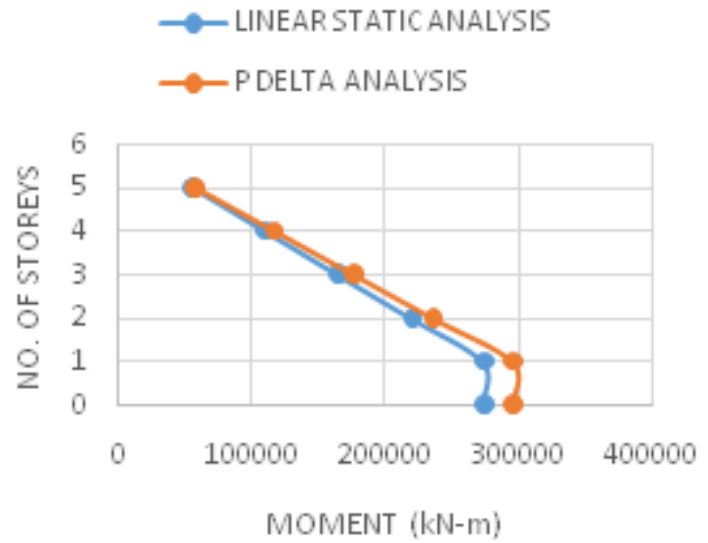

Fig. 7 Variation of Bending moment for the no. of storeys obtained from linear and P-delta analysis for 5 storey model

From the fig. 5The maximum displacement of the 5 storey model is $21.5 \mathrm{~mm}$ and $15 \mathrm{~mm}$ obtained from P-delta analysis and linear analysis respectively and the maximum variation between the two types of analyses is found to be $32.23684211 \%$.

From the fig. 6, the maximum storey shear obtained from Pdelta analysis is $393.8085 \mathrm{kN}$ and that from linear analysis is $315.0487 \mathrm{kN}$ and the maximum variation between the two types of analyses is found to be $19.99888197 \%$.

From the fig. 7, the maximum axial force obtained from Pdelta analysis is $45566.55 \mathrm{kN}$ and that from linear analysis is $42144.31 \mathrm{kN}$ and the maximum variation between the two is found to be $7.510434 \%$.

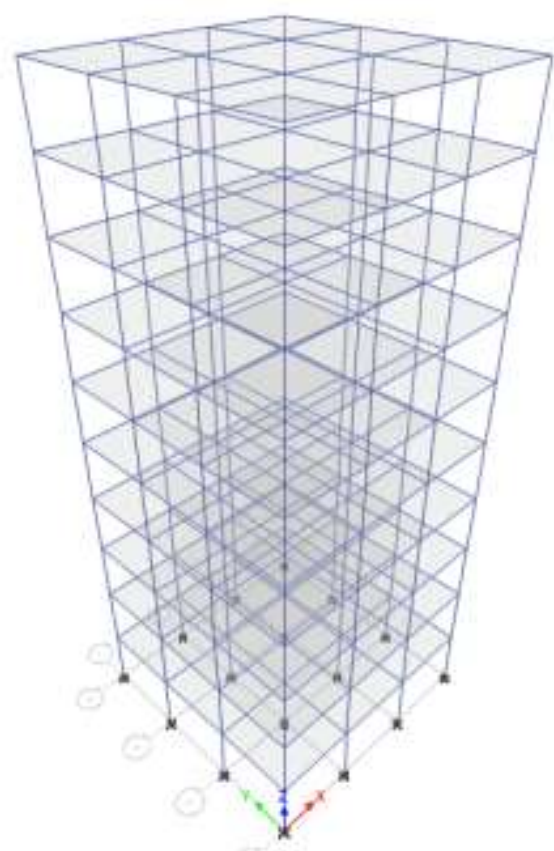

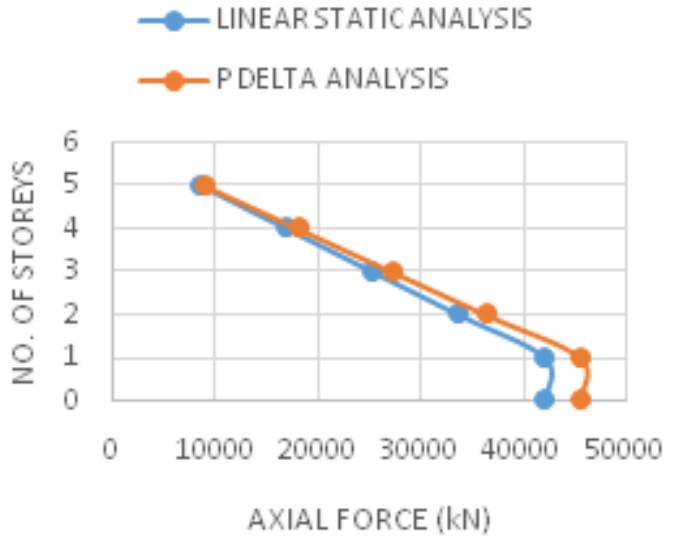

Fig. 8: Variation of Axial force for the no. of storeys obtained from linear and P-delta analysis for 5 storey model

From the fig. 8 , the maximum bending moment obtained from P-delta analysis is $296182 \mathrm{kN}-\mathrm{m}$ and that from linear analysis is $273937 \mathrm{kN}-\mathrm{m}$ and the maximum variation between the two is found to be $7.510584708 \%$.

\subsection{Case 2 - 10 Storey Model}

The undeformed shape and deformed shape of the 5 storey model is as shown in fig. 3 and 4 respectively. The values of displacements, storey shear, axial force and bending moments for 10 storey model that are obtained by linear analysis and P-Delta analysis are tabulated in table no. 3. The values of displacements, storey shear, axial force and bending moments from linear analysis and P-Delta analysis are compared and variations as percent between the two types of analysis are evaluated and tabulated.

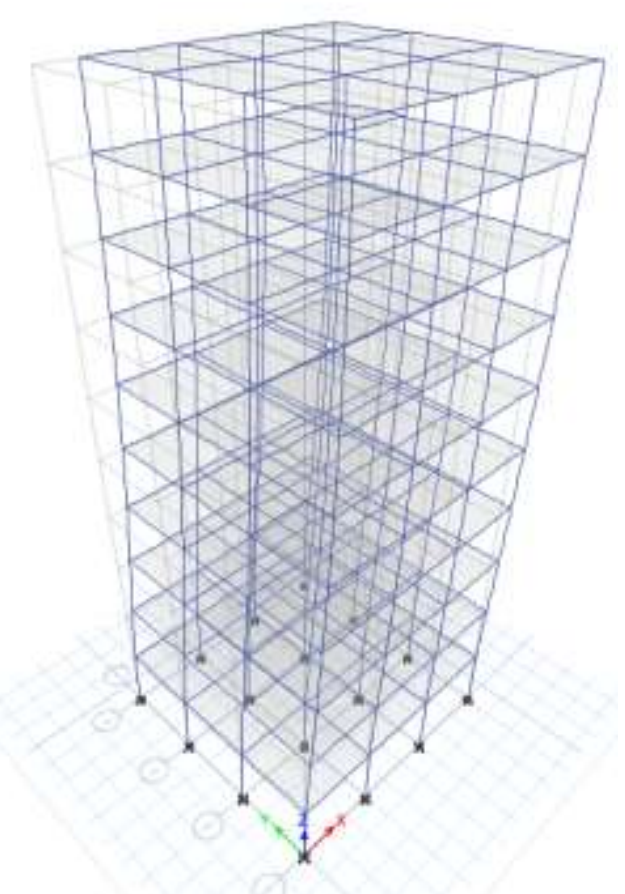

Fig 9. Undeformed shape of 10 storey modelFig 10. Deformed shape of 10 storey model 
The variation of displacements, storey shear, axial force and bending moment obtained from linear static analysis and P-delta analysis are plotted in graphs as shown in fig.11, 12, 13 and 14 respectively.

Table 3: Values of displacements, Storey shear and bending moment for 10 storey model

\begin{tabular}{|l|l|l|l|l|l|l|}
\hline \multirow{2}{*}{$\begin{array}{l}\text { NO OF } \\
\text { STOREYS }\end{array}$} & \multicolumn{2}{|l|}{ DISPLACEMENT (mm) } & \multicolumn{2}{l|}{ STOREY SHEAR(kN) } & \multicolumn{2}{l|}{ MOMENT(kN-m) } \\
\cline { 2 - 7 } & $\begin{array}{l}\text { LINEAR } \\
\text { STATIC } \\
\text { ANALYSIS }\end{array}$ & $\begin{array}{l}\text { P-DELTA } \\
\text { ANALYSIS }\end{array}$ & $\begin{array}{l}\text { LINEAR } \\
\text { STATIC } \\
\text { ANALYSIS }\end{array}$ & $\begin{array}{l}\text { P-DELTA } \\
\text { ANALYSIS }\end{array}$ & $\begin{array}{l}\text { LINEAR } \\
\text { STATIC } \\
\text { ANALYSIS }\end{array}$ & $\begin{array}{l}\text { P-DELTA } \\
\text { ANALYSIS }\end{array}$ \\
\hline 10 & 28.8 & 41.4 & 181.8138 & 227.2653 & 53100.012 & 55044.012 \\
\hline 9 & 27.4 & 39.8 & 350.7402 & 438.4185 & 106200.02 & 112032.02 \\
\hline 8 & 25.5 & 37.4 & 484.2129 & 605.25 & 159300.03 & 169020.03 \\
\hline 7 & 22.9 & 34 & 586.4029 & 732.9727 & 212400.04 & 226008.04 \\
\hline 6 & 19.9 & 29.9 & 661.4814 & 826.8003 & 265500.09 & 282996.06 \\
\hline 5 & 16.5 & 25.1 & 713.6191 & 891.9475 & 318600.31 & 339984.07 \\
\hline 4 & 12.9 & 19.6 & 746.9873 & 933.6297 & 371700.08 & 396972.53 \\
\hline 3 & 9.3 & 13.8 & 765.7569 & 957.0652 & 424800.09 & 453960.75 \\
\hline 2 & 5.6 & 8 & 774.099 & 967.4837 & 477900.96 & 510948.10 \\
\hline 1 & 2.1 & 2.8 & 776.1845 & 970.1496 & 531000.18 & 567936.18 \\
\hline 0 & 0 & 0 & 776.1845 & 970.1496 & 531000.12 & 567936.12 \\
\hline
\end{tabular}

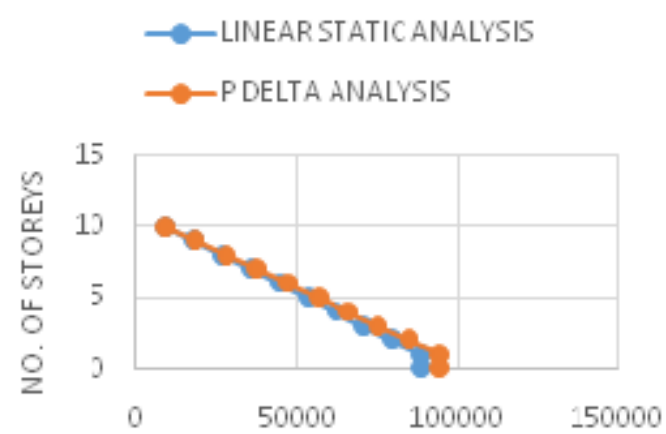

AXIAL FORCE (kN)

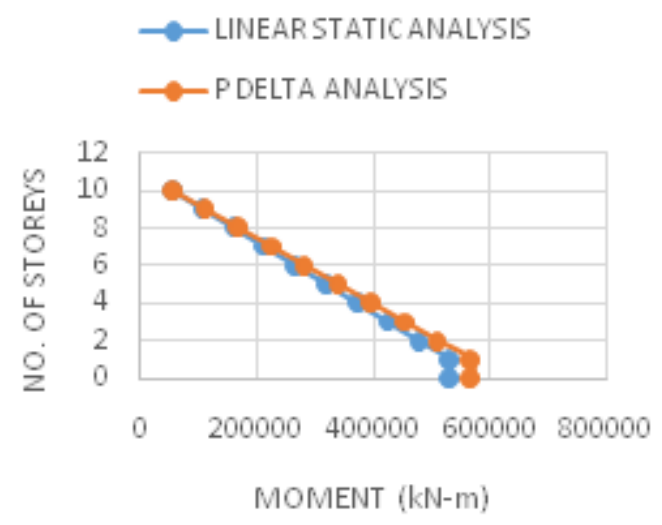

Fig. 11 Variation of Displacement for the no. of storeys Fig.12 Variation of Storey Shear for the no. of storeys obtained from linear and P-delta analysis for 10 storey model obtained from linear and P-delta analysis for 10 storey model
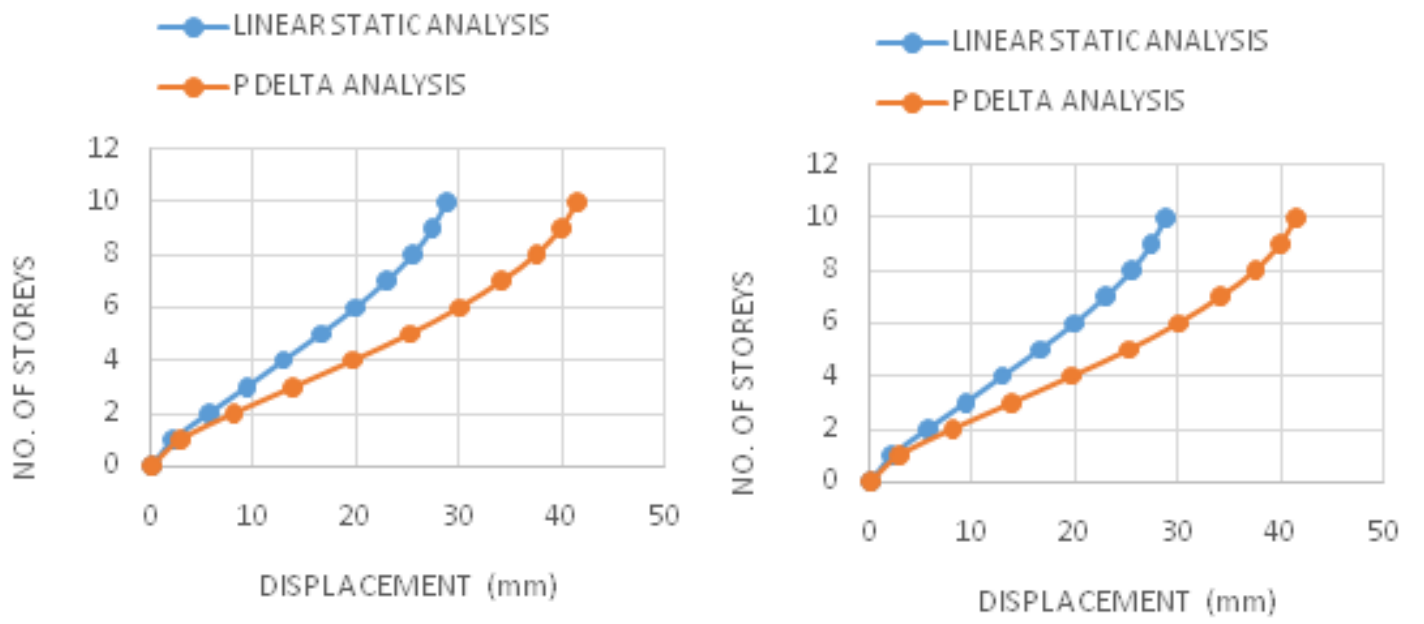

Fig. 13 Variation of Axial Force for the no. of storeys Fig. 14 Variation of Bending Moment for the no. of storeys obtained from linear and P-delta analysis for 10 storey model obtained from linear and P-delta analysis for 10 storey model 
From the fig. 11, the maximum displacement of the 10 storey model is $48.4 \mathrm{~mm}$ and $21.8 \mathrm{~mm}$ obtained from P-delta analysis and linear analysis respectively and the maximum variation between the two is found to be $34.26294821 \%$.

From the fig. 12, the maximum storey shear obtained from P-delta analysis is $970.1496 \mathrm{kN}$ and that from linear analysis is $776.1845 \mathrm{kN}$ and the maximum variation between the two is found to be $20 \%$.

From the fig. 13, the maximum axial force obtained from Pdelta analysis is $94656.0203 \mathrm{kN}$ and that from linear analysis is $88500.0203 \mathrm{kN}$ and the maximum variation between the two is found to be $6.503548301 \%$.

From the fig. 14, the maximum bending moment obtained from P-delta analysis is $567936.1218 \mathrm{kN}-\mathrm{m}$ and that from linear analysis is $531000.1218 \mathrm{kN}-\mathrm{m}$ and the maximum variation between the two is found to be $6.503548301 \%$.

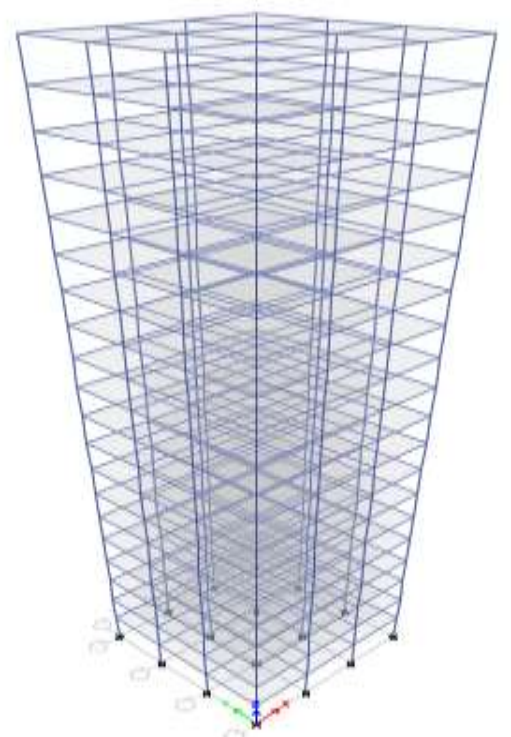

Fig 15. Undeformed shape of 15 storey model

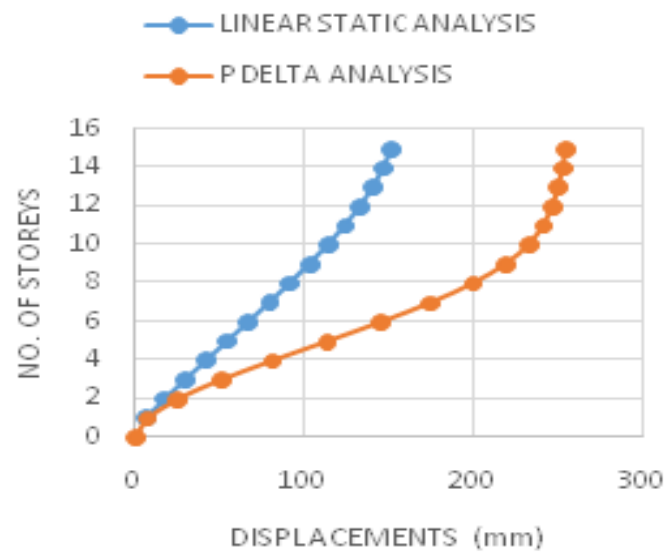

Fig. 17 Variation of Displacement for the no. of storeys obtained from linear and P-delta analysis for 15 storey model
Bending moments are taken from storey 1 of each of each analysis as a maximum bending moment is found in that position. Like the displacement parameter, here also the PDelta outcomes over flow the corresponding case of the Linear Static analysis and represent the necessity of P-delta analysis over the Linear Static for reinforced concrete highrise structures.

\subsection{Case 3 - 15 Storey Model}

The values of displacements, storey shear, axial force and bending moments for 15 storey model that are obtained by linear analysis and P-Delta analysis are tabulated in table no. 4. The values of displacements, storey shear, axial force and bending moments from linear analysis and P-Delta analysis are compared and variations as percent between the two types of analysis are evaluated and tabulated.

The variation of displacements, storey shear, axial force and bending moment obtained from linear static analysis and Pdelta analysis are plotted in graphs as shown in fig.17, 18, 19 and 20 respectively.

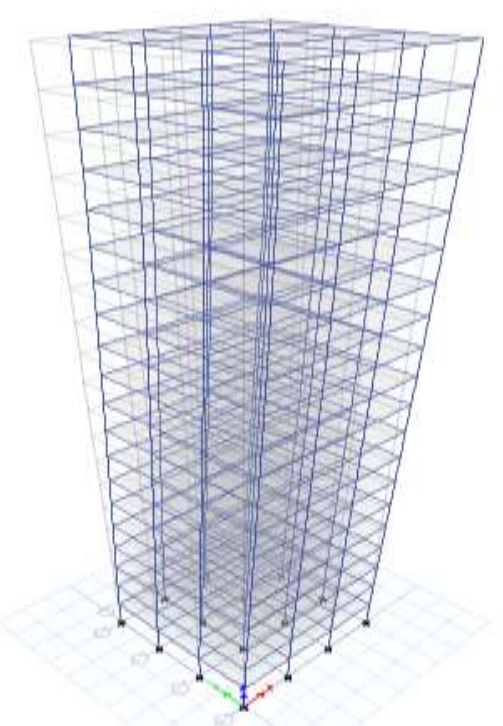

Fig 16. Deformed shape of 15 storey model

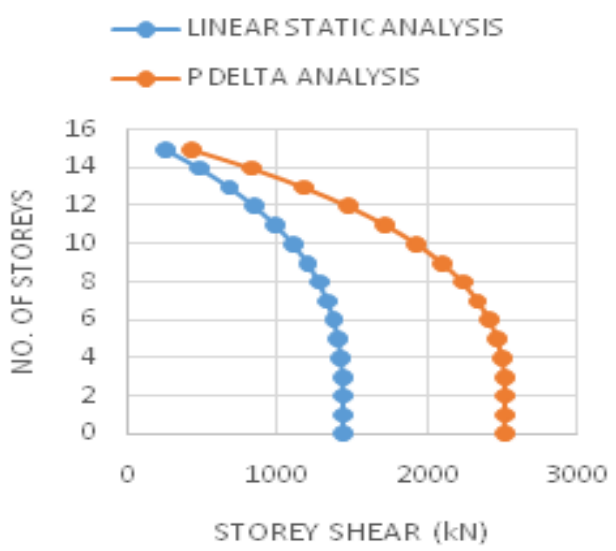

Fig.18 Variation of Storey Shear for the no. of storeys obtained from linear and P-delta analysis for 15 storey model 
Table 4: Values of displacements, Storey shear and bending moment for 15 storey model

\begin{tabular}{|l|l|l|l|l|l|l|}
\hline \multirow{2}{*}{$\begin{array}{l}\text { NO OF } \\
\text { STOREYS }\end{array}$} & \multicolumn{2}{l|}{ DISPLACEMENT $(\mathrm{mm})$} & \multicolumn{2}{l|}{ STOREY SHEAR(kN) } & \multicolumn{2}{l|}{ MOMENT(kN-m) } \\
\cline { 2 - 7 } & $\begin{array}{l}\text { LINEAR } \\
\text { STATIC } \\
\text { ANALYSIS }\end{array}$ & $\begin{array}{l}\text { P-DELTA } \\
\text { ANALYSIS }\end{array}$ & $\begin{array}{l}\text { LINEAR } \\
\text { STATIC } \\
\text { ANALYSIS }\end{array}$ & $\begin{array}{l}\text { P-DELTA } \\
\text { ANALYSIS }\end{array}$ & $\begin{array}{l}\text { LINEAR } \\
\text { STATIC } \\
\text { ANALYSIS }\end{array}$ & $\begin{array}{l}\text { P-DELTA } \\
\text { ANALYSIS }\end{array}$ \\
\hline 15 & 150.8 & 254.2 & 242.6855 & 424.0821 & 52261.6718 & 56058.5468 \\
\hline 14 & 146.3 & 252.2 & 472.3788 & 825.5127 & 104523.34 & 115913.96 \\
\hline 13 & 140.2 & 249.6 & 670.4301 & 1171.7746 & 156785.01 & 175769.39 \\
\hline 12 & 132.6 & 246 & 839.1833 & 1467.2054 & 209046.68 & 235624.81 \\
\hline 11 & 123.7 & 240.8 & 980.9823 & 1716.2115 & 261308.35 & 295480.23 \\
\hline 10 & 113.7 & 232.2 & 1098.1707 & 1922.9111 & 313570.03 & 355335.65 \\
\hline 9 & 102.8 & 218.6 & 1193.0913 & 2091.1813 & 365831.70 & 415191.07 \\
\hline 8 & 91.3 & 199.3 & 1268.0851 & 2224.8957 & 418093.37 & 475046.49 \\
\hline 7 & 79.3 & 174.5 & 1325.5054 & 2327.8449 & 470355.04 & 534901.92 \\
\hline 6 & 67 & 145.3 & 1367.6905 & 2403.7527 & 522616.74 & 594757.34 \\
\hline 5 & 54.6 & 113.4 & 1396.9817 & 2456.3005 & 574878.39 & 654612.76 \\
\hline 4 & 42.1 & 80.9 & 1415.7126 & 2489.1659 & 627140.06 & 714468.18 \\
\hline 3 & 29.8 & 50.5 & 1426.238 & 2506.0591 & 679401.73 & 774323.60 \\
\hline 2 & 17.8 & 25 & 1430.8953 & 2510.6907 & 731663.40 & 834179.03 \\
\hline 1 & 6.7 & 7.2 & 1431.9097 & 2506.8362 & 783925.07 & 894034.45 \\
\hline 0 & 0 & 0 & 1431.9097 & 2506.8362 & 783925.07 & 894034.45 \\
\hline
\end{tabular}

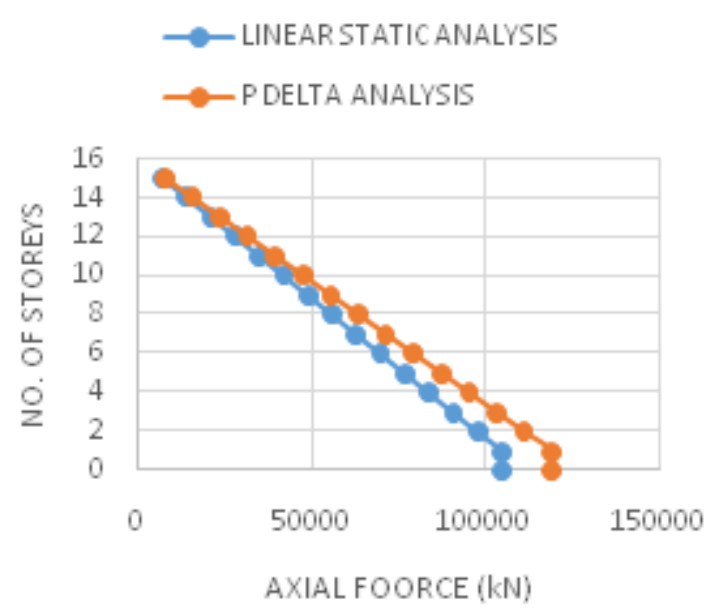

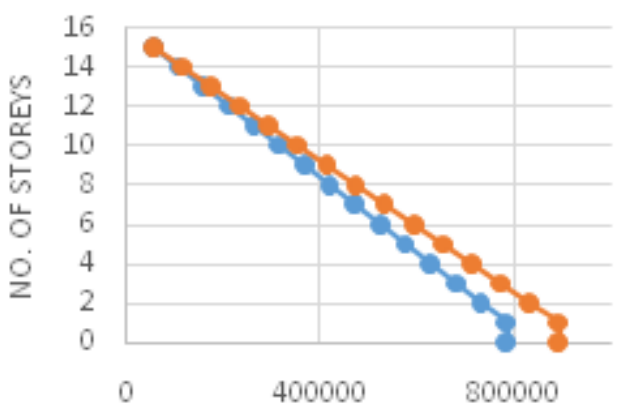

MOMENT $(\mathrm{kN}-\mathrm{m})$

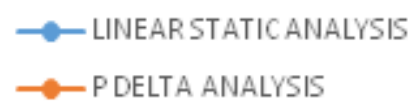

Fig. 19 Variation of Axial force for the no. of storeys Fig. 20 Variation of Bending Moment forthe no. of storeys obtained from linear and P- delta analysis for 15 storey model obtained from linear and P-delta analysis for 15 storey model

From the fig. 17, the maximum displacement of the 15 storey model is $254.2 \mathrm{~mm}$ and $150.8 \mathrm{~mm}$ obtained from Pdelta analysis and linear analysis respectively and the maximum variation between the two is found to be $54.18966382 \%$.

From the fig. 18, the maximum storey shear obtained from P-delta analysis is $2506.8362 \mathrm{kN}$ and that from linear analysis is $1431.9097 \mathrm{kN}$ and the maximum variation between the two is found to be $43.12659628 \%$. Storey shear are taken from storey 1 to storey 15 of each analysis and it is found that storey shear is maximum in case of P-delta analysis when compared to linear static analysis. Like the displacement and bending moment parameters, the variation in storey shears obtained from linear static analysis and Pdelta analysis represent the necessity of P-delta analysis over the Linear Static for reinforced concrete high-rise structures.

From the fig. 19, the maximum axial force obtained from Pdelta analysis is $119204.5937 \mathrm{kN}$ and that from linear analysis is $104523.3437 \mathrm{kN}$ and the maximum variation between the two is found to be $12.31601027 \%$. 
From the fig. 20,the maximum bending moment obtained from P-delta analysis is $894034.4526 \mathrm{kN}-\mathrm{m}$ and that from linear analysis is $783925.0776 \mathrm{kN}-\mathrm{m}$ and the maximum variation between the two is found to be $12.31601027 \%$.

\subsection{Case4: 20 Storey Model}

The values of displacements, storey shear, axial force and bending moments for 20 storey model that are obtained by linear analysis and P-Delta analysis are tabulated in table no.

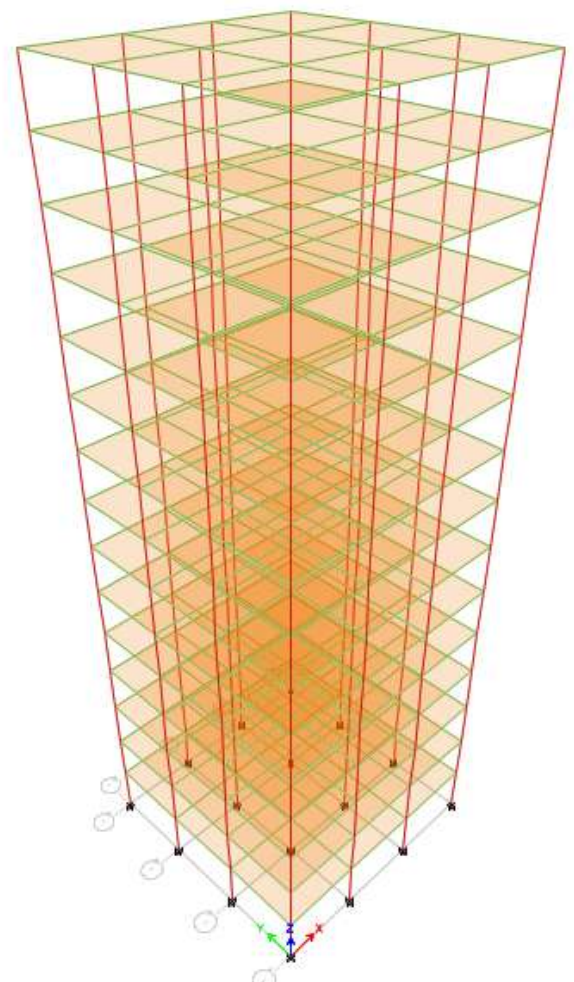

Fig.21 Undeformed shape of 20-storey mode

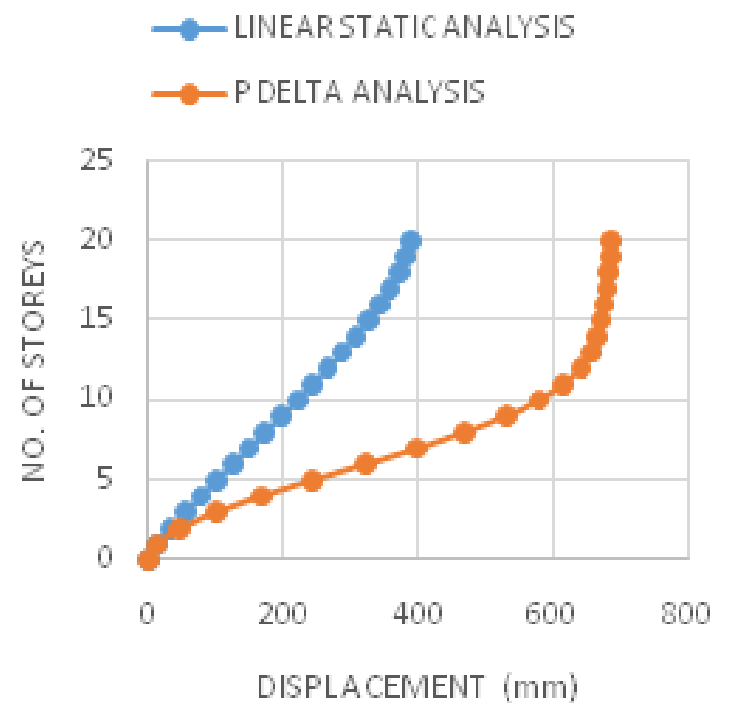

Fig.23 Variation of Displacement for the no. of storeys obtained from linear and P-delta analysis for 20 storey mode
5. The values of displacements, storey shear, axial force and bending moments from linear analysis and P-Delta analysis are compared and variations as percent between the two types of analysis are evaluated and tabulated.

The variation of displacements, storey shear, axial force and bending moment obtained from linear static analysis and Pdelta analysis are plotted in graphs as shown in fig. 23, 24, 25 and 26 respectively.

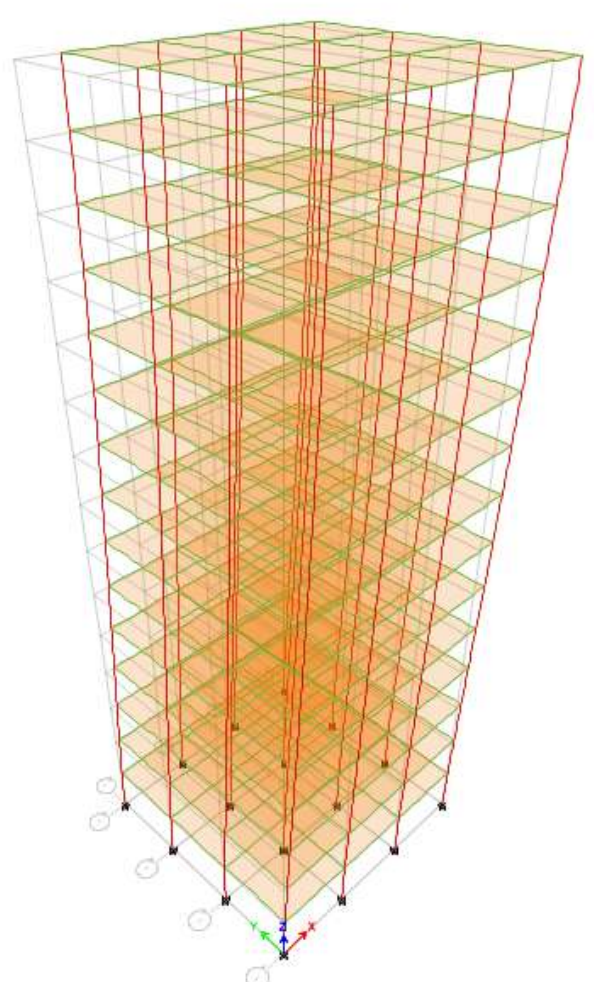

Fig. 22 Deformed shape of 20 storey model

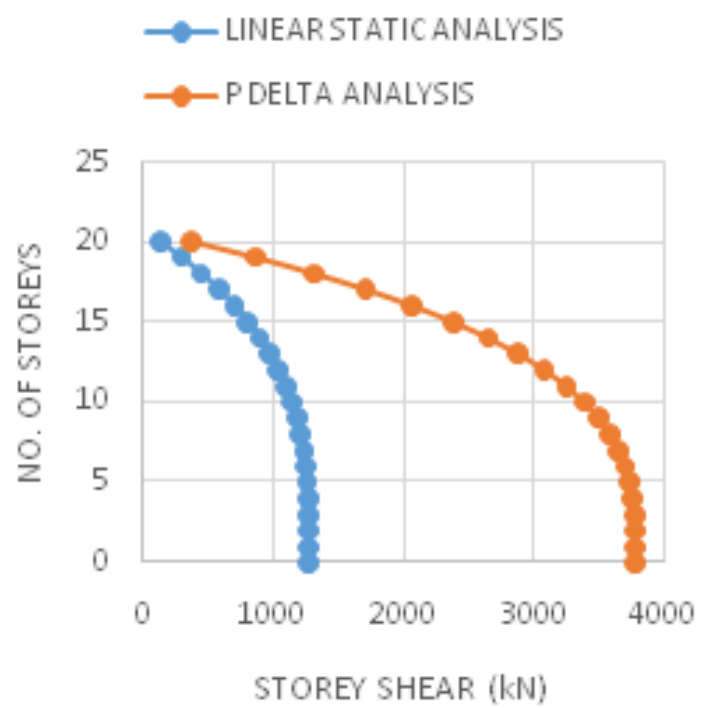

Fig. 24 Variation of Storey Shear for the no. of storeys obtained from linear and P-delta analysis for 20 storey model 
Table 5 Values of displacements, Storey shear and bending moment for 20 storey model

\begin{tabular}{|c|c|c|c|c|c|c|}
\hline \multirow{2}{*}{$\begin{array}{l}\text { NO OF } \\
\text { STOREYS }\end{array}$} & \multicolumn{2}{|c|}{ DISPLACEMENT (mm) } & \multicolumn{2}{|c|}{ STOREY SHEAR(kN) } & \multicolumn{2}{|c|}{ MOMENT(kN-m) } \\
\hline & $\begin{array}{l}\text { LINEAR } \\
\text { STATIC } \\
\text { ANALYSIS }\end{array}$ & $\begin{array}{l}\text { P-DELTA } \\
\text { ANALYSIS }\end{array}$ & $\begin{array}{l}\text { LINEAR } \\
\text { STATIC } \\
\text { ANALYSIS }\end{array}$ & $\begin{array}{l}\text { P-DELTA } \\
\text { ANALYSIS }\end{array}$ & $\begin{array}{l}\text { LINEAR } \\
\text { STATIC } \\
\text { ANALYSIS }\end{array}$ & $\begin{array}{l}\text { P-DELTA } \\
\text { ANALYSIS }\end{array}$ \\
\hline 20 & 390 & 686.3 & 122.2906 & 361.9837 & 14044.8497 & 14044.8497 \\
\hline 19 & 381.9 & 684.4 & 291.5067 & 862.8673 & 42466.5416 & 44095.468 \\
\hline 18 & 371.4 & 681.9 & 443.3802 & 1312.4139 & 70888.2335 & 76400.0629 \\
\hline 17 & 358.5 & 678.9 & 578.8486 & 1713.3983 & 99309.9254 & 110727.617 \\
\hline 16 & 343.4 & 675.4 & 698.8495 & 2068.5956 & 127731.617 & 146859.601 \\
\hline 15 & 326.3 & 671.3 & 804.322 & 2380.7807 & 156153.309 & 184589.974 \\
\hline 14 & 307.6 & 665.9 & 896.2153 & 2652.7287 & 184575.001 & 223725.179 \\
\hline 13 & 287.5 & 657.1 & 975.5296 & 2887.2144 & 212996.693 & 264084.150 \\
\hline 12 & 266.1 & 641.3 & 1043.3707 & 3087.0129 & 241418.385 & 305498.306 \\
\hline 11 & 243.9 & 615.8 & 1100.6325 & 3254.8991 & 269840.076 & 347811.556 \\
\hline 10 & 220.9 & 578.8 & 1148.049 & 3393.648 & 298261.768 & 390880.294 \\
\hline 9 & 197.3 & 529.7 & 1186.5322 & 3506.0347 & 326683.460 & 434573.402 \\
\hline 8 & 173.4 & 469.1 & 1216.984 & 3594.834 & 355105.152 & 478772.250 \\
\hline 7 & 149.4 & 398.8 & 1240.3059 & 3662.821 & 383526.844 & 523370.695 \\
\hline 6 & 125.3 & 321.9 & 1257.3968 & 3712.7706 & 411948.536 & 568275.081 \\
\hline 5 & 101.4 & 242.9 & 1269.1549 & 3747.4578 & 440370.228 & 613404.240 \\
\hline 4 & 77.8 & 167.3 & 1276.4776 & 3769.6576 & 468791.920 & 658689.492 \\
\hline 3 & 54.6 & 100.5 & 1280.2664 & 3782.145 & 497213.612 & 704074.644 \\
\hline 2 & 32.3 & 47.5 & 1281.4165 & 3787.695 & 525635.304 & 749515.988 \\
\hline 1 & 11.9 & 12.9 & 1280.8582 & 3789.0825 & 554056.996 & 794982.308 \\
\hline 0 & 0 & 0 & 1280.8582 & 3789.0825 & 554056.996 & 794982.308 \\
\hline
\end{tabular}

From the fig. 23, the maximum displacement of the 20 storey model is $686.3 \mathrm{~mm}$ and $390 \mathrm{~mm}$ obtained from Pdelta analysis and linear analysis respectively and the maximum variation between the two is found to be
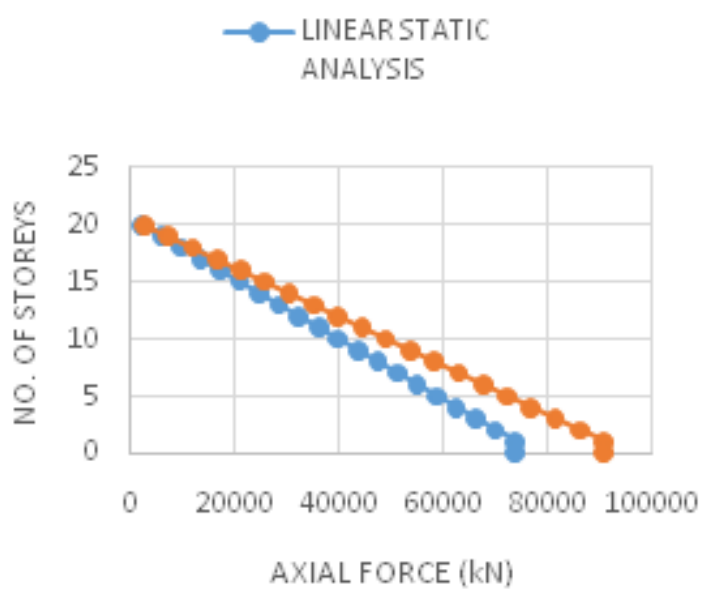

$63.03560009 \%$. From the fig. 24, the maximum storey shear obtained from P-delta analysis is $3789.0825 \mathrm{kN}$ and that from linear analysis is $1280.8582 \mathrm{kN}$ and the maximum variation between the two is found to be $66.21208318 \%$.

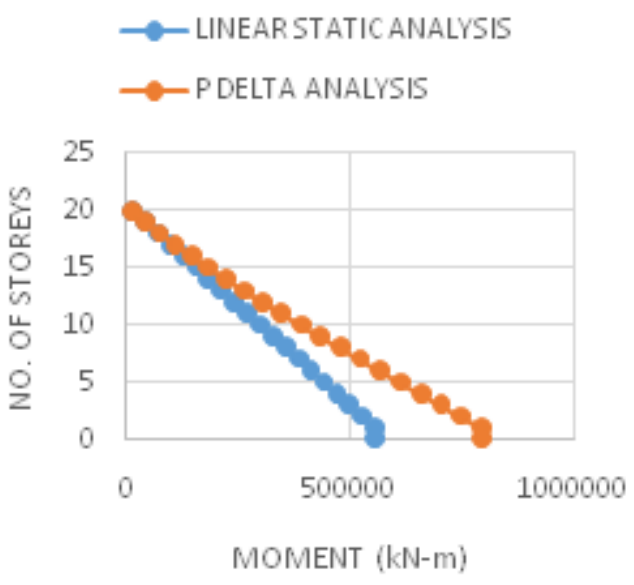

Fig. 25 Variation of Axial Force for the no. of storeys Fig. 26 Variation of Bending Moment for the no. of storeys obtained from linear and P-delta analysis for 20 storey model obtained from linear and P-delta analysis for 20 storey model 
From the fig. 25, the maximum axial force obtained from Pdelta analysis is $90782.2721 \mathrm{kN}$ and that from linear analysis is $73874.2661 \mathrm{kN}$ and the maximum variation between the two is found to be $29.47899128 \%$.

From the fig. 26, the maximum bending moment obtained from P-delta analysis is $794982.3083 \mathrm{kN}-\mathrm{m}$ and that from linear analysis is $554056.9961 \mathrm{kN}-\mathrm{m}$ and the maximum variation between the two is found to be $30.30574513 \%$.

All the parameters such as displacements, storey shear and bending moments for all the four model considered increases with increasing height or addition of storey. On the other side, analysis conducted without considering PDelta effects leads to increment of moment with increment
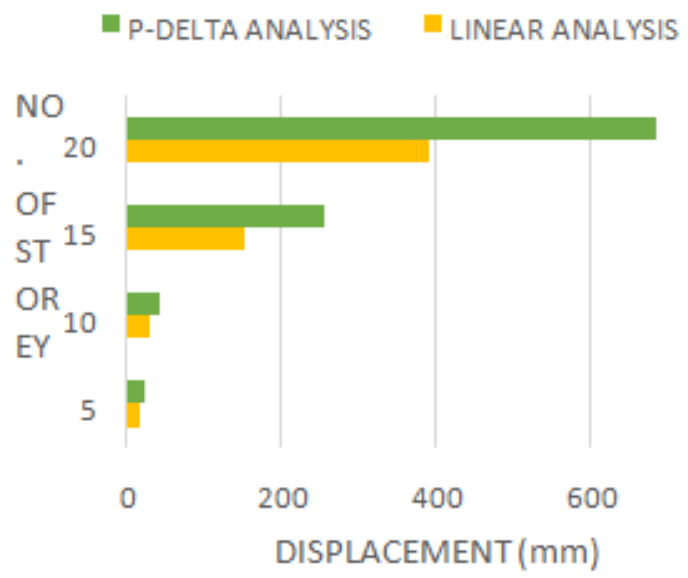

Fig. 27 Comparison of displacements for the no. of storeys obtained from linear and P-delta analysis

\section{P-DELTA ANALYSIS " LINEAR ANALYSIS}

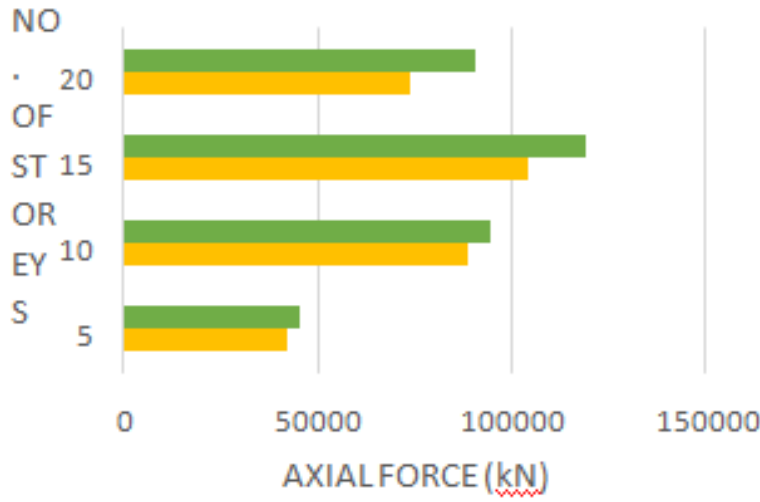

Fig.29 Comparison of axial force for the no. of storeys obtained from linear and $\mathrm{P}$ - delta analysis of storey as it was expected. Overall high-rise shows higher value then low-rise construction under this analysis.

From the fig 25 and fig 26, the variation of axial force and bending moment obtained from linear static analysis and Pdelta analysis in the top storeys have nearly the same values and in the bottom storeys the variation is more and maximum at the base.

The comparison of displacements, base shear, axial force and bending moment that are obtained from linear static analysis and P-Delta analysis for the 5, 10, 15 and 20 storeys are tabulated in table no. 6 and the same is plotted in fig 27 , 28,29 and 30 respectively.

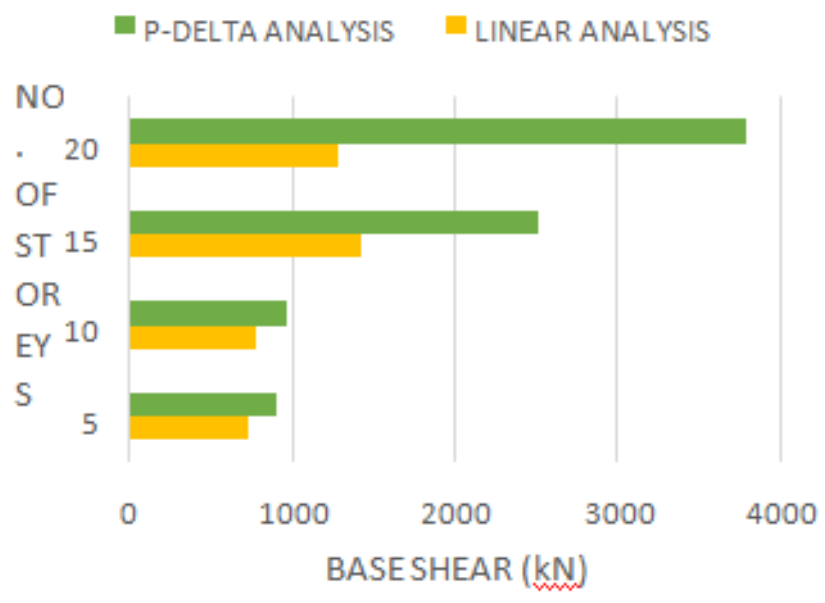

Fig. 28 Comparison of base shear for the no. of storeys obtained from linear and $\mathrm{P}$ delta analysis

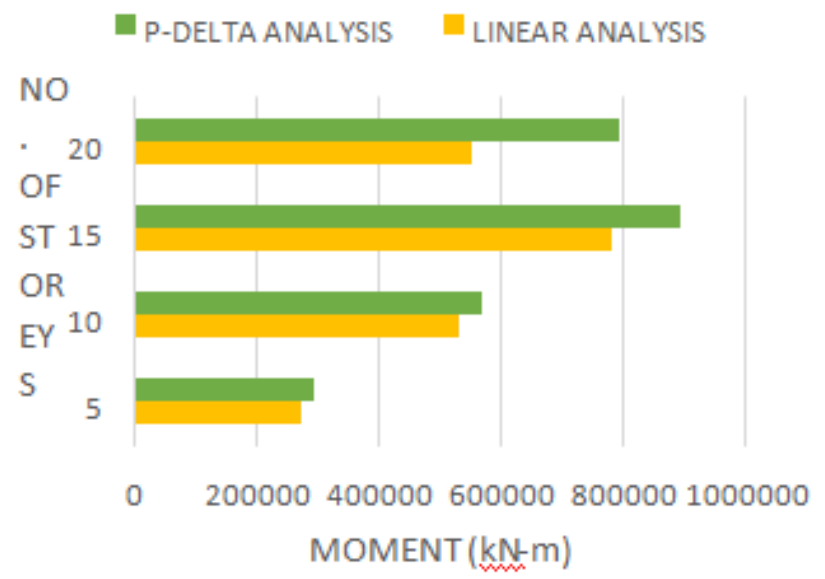

Fig.30 Comparison of bending moment for the no. of storeys obtained from linear and P-delta analysis

Table 6: Variation in axial force, displacement, storey shear and bending moment for various models considered for the study

\begin{tabular}{|l|l|l|l|l|}
\hline \multirow{2}{*}{ MODEL } & \multicolumn{4}{|c|}{ VARIATION (\%) } \\
\cline { 2 - 5 } & Displacement & Axial force & Storey shear & Moment \\
\hline G+4 & 32.2368 & 7.5104 & 19.9995 & 6.9841 \\
\hline $\mathbf{G + 9}$ & 34.2629 & 6.5035 & 19.9966 & 6.4679 \\
\hline $\mathbf{G + 1 4}$ & 54.5558 & 12.3160 & 43.1265 & 12.31 \\
\hline $\mathbf{G + 1 9}$ & 63.0356 & 29.4789 & 66.2153 & 30.3057 \\
\hline
\end{tabular}




\section{CONCLUSION}

- The results of storey shear obtained from 20 storey and 15 storey model, when analysed for P-delta effect shows respectively $66.21 \%$ and $43.12 \%$ more than that obtained from linear static analysis.

- The results of axial force obtained from 20 storey and 15 storey model, when analysed for P-delta effect shows respectively $29.47 \%$ and $12.31 \%$ more than that obtained from linear static analysis.

- The results of displacements obtained from 20 storey and 15 storey model, when analysed for P-delta effect shows respectively $63.03 \%$ more than that obtained from linear static analysis.

- The results of bending moments obtained from 20 storey and 15 storey model, when analysed for P-delta effect shows respectively $30.305 \%$ and $12.31 \%$ more than that obtained from linear static analysis.

- From the results obtained, it can be concluded that the P-delta effect should be considered in analysis of multistoried buildings.

\section{REFERENCES}

[1] Christoph ADAM, Luis F. Ibarra, Helmut Krawinkler, 2004, "Evaluation of p-delta effects in nondeteriorating MDOF structures from equivalent SDOF systems", $13^{\text {th }}$ World Conference on Earthquake Engineering Vancouver, B.C., Canada, Page no. 3407.

[2] A.S. Moghadam and A. Aziminejad, 2004,"Interaction of torsion and P-delta effects in tall buildings", $13^{\text {th }}$ World Conference on Earthquake Engineering Vancouver, B.C., Canada, Page no. 799.

[3] Shah B.A, Patel P.V, 2005, "Seismic evaluation of RCC framed structures using static pushover analysis", International conference on recent trends in concrete technology and structures", Kumara guru college of technology, Coimbatore, pp. 658-665.

[4] Peng, B.H.H., Dhakal, R.P., Fenwick, R.C., Car, A.J., Bull, D.K.2007, "Flexural, Axial Load and Elongation Response of Plastic Hinges in Reinforced Concrete Member," Proceedings of $8^{\text {th }}$ Pacific Conference of Earthquake Engineering, Singapore. Paper No. 30.

[5] Priestley, M.J.N., Calvi, G.M., Kowalsky, M.J.2007, "Displacement Based Seismic Design of Structures", IUSS Press, Pavia, Italy.

[6] T.J. Sullivan, T.H. Pham and G.M. Calvi, 2008,"Pdelta effects on tall RC frame-wall buildings", The $14^{\text {th }}$ World Conference on Earthquake Engineering Beijing, China October 12-17.

[7] Pham, T.H., "Seismic Design Considerations for Tall Buildings" MEEES Masters Dissertation supervised by Sullivan, T.J. and Calvi, G.M., held at ROSE School, University of Pavia, Italy. 85pages, 2008.

[8] Jose Antonio Flores Ruiz,2015,"Study of P-Delta Effect on Tall Steel Structure", International Journal of Allied Practice, Research and Review, Page No. 26-36. 